\title{
Effect of Vermicomposting on the Concentration of Heavy Metals in Soil with Drill Cuttings
}

\author{
Justyna Kujawska ${ }^{*}$, Katarzyna Wójcik-Oliveira ${ }^{1}$ \\ 1 Faculty of Environmental Engineering, Lublin University of Technology, Nadbystrzycka 40B, 20-618 Lublin, \\ Poland \\ * Corresponding author's e-mail: j.kujawska@pollub.pl
}

\begin{abstract}
Organic and non-organic pollution present in the drilling waste may negatively impact flora and fauna. The tests conducted on earthworms may serve as indicators for the assessment of pollution bioavailability, i.a. heavy metals, polycyclic aromatic hydrocarbons, due to the relatively stable ratios between the concentration of certain pollutants in earthworms and soil. Moreover, earthworms are capable of metal bioaccumulation in tissues; therefore, they can be utilized as an ecological indicator of soil pollution. The studies on bioaccumulation of heavy metals from soils with the addition of drilling wastes in tissues of earthworms were conducted. The reduction percentage (R) of each scenario was calculated for the total concentration of all heavy metals. As data showed, all heavy metal content was reduced from its initial concentration.
\end{abstract}

Keywords: drill cuttings, vermicomposting, heavy metals

\section{INTRODUCTION}

In recent decades, an increased demand for natural gas is observed around the world. The growing need for electricity and the aims for European energy policy are favourable factors for the investments related to the exploration of crude oil and natural gas, both from the conventional and non-conventional deposits [Kaliski et al. 2010]. The first natural gas mining license from nonconventional hydrocarbon deposits was issued in 2007. Five years later, already over a hundred of such licenses were issued. Until October 2017, seventy-two exploratory wells were drilled.

Exploration of non-conventional gas deposits, mainly shale gas, produces a large amount of various drilling wastes. These include, among others, drill fluids and wastes containing crude oil, hazardous substances, barite, chlorides as well as non-drilling wastes, including the wastes containing mercury, plastics, varnishes, dyes, and oils (engine, hydraulic). During drilling of an exploratory hole at the depth up to $3000 \mathrm{~m}$,
$2,849,000 \mathrm{~kg}$ of spent drill fluid and drilling wastes is produced [Macuda 2010].

This kind of waste may contain high concentrations of substances which are hazardous for the environment, i.e. heavy metals, mainly, arsenic, barium, chromium, copper, lead, nickel and zinc, as well as complex organic compounds, i.e. aliphatic and aromatic hydrocarbons [McFarland et al., 2009].

Increasing amount of drilling wastes and their physicochemical properties enforce conducting studies on their impact on the environment as well as devising the methods for their management. In Poland, storage is the most popular method for the management of drilling wastes. In the United States, bioremediation methods are most often employed for this purpose. One of novel methods of management involves utilization of earthworms. Vermicomposting constitutes an established method of treating organic wastes [Liu et al., 2005, Suthar et al., 2008]. Vermicompositng is a biochemical process of organic material degradation (Fu et al., 2015) constituting a joint op- 
eration of earthworms and microorganisms in the aerobic state, which is capable of transforming majority of organic elements into valuable products, rich in nitrogen, phosphorus and potassium [Lv et al., 2016].

Earthworms (especially Eisenia fetida) are mainly used for vermicomposting of sewage sludge. An important feature of vermicompost includes lower content of heavy metals, i.e. $\mathrm{Pb}, \mathrm{Cd}$ and $\mathrm{Zn}$ in relation to the sludges prior to vermicomposting. The studies confirm that earthworms are sorbents of heavy metals [Li et al., 2005].

Earthworms tend to bioaccumulate trace compounds from the soil environment [Hobbelen et al., 2006]. The bioaccumulation degree depends on the concentration of particular compounds, soil $\mathrm{pH}$, and the concentration of organic carbon. Earthworms are most efficient in absorbing cadmium and lead ions. Although the zinc ions may reduce their capacity of rapid movement, and the organoleptic symptoms include the swelling of earthworms and unnatural narrowing of their bodies, whereas lead ions in high concentrations lead to the decomposition of tegument and the loss of coelomic fluids [Spurgeon 2003, Udovic and Lestan 2010]. In an acidic soil, the accumulation of trace elements is carried out more efficiently. Most of heavy metal ions contained in soil have an impact on the metabolism and in excessive concentrations it may cause death of living organisms [Lukari et al., 2004].

The vermicomposting process was only recently used in with drill fluids. In the bioremediation process of drill cuttings mixed with soil and organic matter, the content of oil derivatives in cuttings was reduced to background levels [Norman 2002, Getliff 2002, Enuneku and Ayobahan 2016].

Norman et al. conducted the vermicomposting of drill cuttings based on paraffins with removed chlorides. Experience has shown that the combination of vermiculture and a chloride-free synthetic drilling fluid (designed for optimal bioremediation potential and low residual electrical conductivity) gives fast and efficient degradation of the hydrocarbons to background levels, with no deleterious effects on the worms [Norman 2002].

The paper investigated the heavy metal content in the soils processed by earthworms, which contained an addition of drilling wastes comprising water-based drill fluids. Determining the total content of heavy metal indicates total soil contamination but it is not useful for determining the bioavailability. The reduction percentage $(\mathrm{R})$ of each scenario was calculated.

\section{MATERIALS AND METHODS}

The chernozem soil was collected in the vicinity of Hrubieszów (eastern Poland) from arable soil (up to the depth of $30 \mathrm{~cm}$ ). The waterbased drilling wastes were taken from the facility of mining waste, produced during shale gas searching in eastern Poland. Mixtures of soil and drill cuttings were prepared, which differed in respect to the composition.

\section{Research methodology}

The assay was carried out in glass containers with the volume of $250 \mathrm{~cm}^{3}$, filled with soil containing an addition of water- and oil-based drilling cuttings.

Each sample contained 10 mature Eisenia fetida earthworms. Chernozem soil constituted the control sample. The water content amounted to $40 \div 60 \%$ (WHC). The assay was carried out over the period of 7 days. The earthworms were fed with finely ground manure.

\section{Analytical methods}

\section{Determination of physicochemical properties}

- electrical conductivity-measured for 1:5 soil/ water (weight/volume), (PN-EN 27888:1999 soil quality. Determination of the specific electrical conductivity)

- $\mathrm{pH}$ value by means of potentiometric method in water solution and in $1 \mathrm{M}$ solution of potassium chloride (PN-ISO 10390: 1997P soil quality. Determination of $\mathrm{pH}$ ),

- dry matter content by means of loss on drying method in the temperature of $105^{\circ} \mathrm{C}$ (PN EN ISO 11465:1999P soil quality. Determination of dry matter content of soil and water in soil per dry mass of soil. Gravimetric method),

- total heavy metals were determined by ICPOES Ultrace 238 (Jobin Yvon-Horriba France) using direct calibration method after microwave digestion (Multiwave 3000, Anton Paar).

Table 1. Composition of mixtures

\begin{tabular}{|c|c|c|}
\hline \multirow{2}{*}{ Sample } & \multicolumn{2}{|c|}{ Composition (\% weight) } \\
\cline { 2 - 3 } & Soil & Drill cuttings \\
\hline A5 & $95 \%$ & $5 \%$ \\
\hline A10 & $90 \%$ & $10 \%$ \\
\hline A15 & $85 \%$ & $15 \%$ \\
\hline
\end{tabular}


The samples of homogenized soil $(1 \mathrm{~g})$ were digested in acid mixture of $\mathrm{HNO}_{3}: \mathrm{HCl}(5: 2)$ and water samples $(15 \mathrm{~g})$ were digested in $\mathrm{HNO}_{3}$ $\left(\mathrm{cm}^{3}\right)$. The digestion process lasted $45 \mathrm{~min}$ at $180^{\circ} \mathrm{C}$ and at the pressure of 18 bars. Metal concentrations were determined at different wavelengths $(213-395 \mathrm{~nm})$. Detection limits for particular metals did not exceed $10 \mathrm{ppb}$.

The reduction percentage (R) of each scenario was calculated for the total concentration of all heavy metals. The $\mathrm{R}$ values were determined using the following equation [Wang et al., 2013]:

$$
R=\frac{c_{i}-c_{f}}{c_{i}} \cdot 100 \%
$$

where: $C_{i}$ is the concentration of heavy metals in the raw materials $(\mathrm{mg} / \mathrm{kg})$, and

$C_{f}$ denotes the same for vermicompost after 7 day.

Mean values with standard deviation were calculated for the results of this study. Then, the statistical analyses based on the one-way analysis of variance (ANOVA) and multiple T-Tukey tests with the significance level $\alpha=0.05$ were carried out. T-Tukey's multiple comparative tests provided a detailed comparative analysis of mean values by isolating statistically homogeneous groups (homogeneous groups). The matrix of correlation coefficients between the variables was determined.

\section{RESULTS AND DISCUSSION}

The characteristics of physicochemical properties of the materials used in the experiment and investigated mixtures were presented in Table 2.

The studied soil was collected from the layer of $0-30 \mathrm{~cm}$ in the vicinity of Bychawa. On the basis of the sieve grain analysis, it was classified as lessive soil, due to the dominant share of dust fraction $(71 \%)$ and sand fraction (23\%). The soil was characterized by acidic $\mathrm{pH}(4.7)$ as well as low organic matter (2\%) and metal content. The drilling wastes used in the experiment had an alkaline $\mathrm{pH}$ (8) and a high content of organic matter (12\%).

As indicated in the studies by He et al. [2016], the optimal activity of earthworms in organic materials occurs at adequate physicochemical properties, i.a. pH ranging from 5 to 8 , humidity of $40-55 \%$ and $\mathrm{C} / \mathrm{N}$ ratio approximating $30 \%$. The prepared mixtures are characterized with the $\mathrm{pH}$ which is optimal for the growth of earthworms, high organic matter content (about 2\%). The con- tent of organic carbon in the produced mixtures is fourty-fold higher in relation to the applied soil.

The $\mathrm{pH}$ in vermicompost (soil with various doses of drilling wastes following 7 days of residence of earthworms) was decreased by 1 . The reduced $\mathrm{pH}$ is caused by the microbiological metabolism coupled with the decomposition of organic matter [Fu et al., 2015]. The organic carbon content in vermicompost is reduced by $0.2 \%$. The loss of carbon might be caused by the respiration of microorganisms and stabilization of organic matter content by earthworms [Liu et al., 2005]. All parameters showed significant difference after vermicomposting treatment. The variation in $\mathrm{pH}, \mathrm{EC}, \mathrm{TOC}$ and $\mathrm{GI}$ in all trials were significant $(p<0,05)$

The concentration of metals in the materials used for the preparation of mixtures was presented in Table 3. The content of metals in drilling wastes is much higher than in soil. Such values of heavy metals in drilling wastes raise concerns in terms of their infiltration into soils or surface and ground waters. However, the concentrations of metals in drilling wastes do not exceed the limit established in the regulation pertaining to the method of assessing surface pollution [Journal of Laws 2016 item 1395]. Total content of metals in the parent mixtures and vermicompost was presented in Figures 1-3.

Table 2. Initial and final characterization of physical and chemical properties of mixtures ${ }^{z}$.

\begin{tabular}{|c|c|c|c|}
\hline \multirow{2}{*}{ Sample } & \multicolumn{3}{|c|}{ Composition (\% weight) } \\
\cline { 2 - 4 } & $\mathrm{pH}$ & TOC [\%] & $\begin{array}{c}\text { Moisture } \\
\text { content [\%] }\end{array}$ \\
\hline Drill cuttings & $8 \pm 0.1$ & $6.2 \pm 0.5$ & \\
\hline Soil & $4.7 \pm 0.2$ & $\begin{array}{c}0.03 \pm \\
0.001\end{array}$ \\
\hline \multicolumn{4}{|c|}{ Initial characterization of mixtures } \\
\hline A5 & $7.5^{\mathrm{a}} \pm 0,1$ & $\begin{array}{c}1,30^{\mathrm{a}} \pm \\
0.52\end{array}$ & $32^{\mathrm{a}} \pm 1.3$ \\
\hline A10 & $7.8^{\mathrm{c}} \pm 0.1$ & $1.37^{\mathrm{c}} \pm 0.6$ & $33^{\mathrm{a}} \pm 2.1$ \\
\hline A15 & $8.0^{\mathrm{e}} \pm 0.2$ & $1.48^{\mathrm{e}} \pm 0.5$ & $35^{\mathrm{a}} \pm 3.1$ \\
\hline \multicolumn{5}{|c|}{ Final characterization of mixtures } \\
\hline A5 & $6.6^{\mathrm{b}} \pm 0.2$ & $1.10^{\mathrm{b}} \pm 0.4$ & $34^{\mathrm{a}} \pm 1.1$ \\
\hline A10 & $6.9^{\mathrm{d}} \pm 0.1$ & $1.17^{\mathrm{d}} \pm 0.3$ & $35^{\mathrm{a}} \pm 1.3$ \\
\hline A15 & $7.1^{\mathrm{f}} \pm 0.2$ & $1.21^{\mathrm{f}} \pm 0.1$ & $37^{\mathrm{a}} \pm 1.5$ \\
\hline
\end{tabular}

${ }^{\mathrm{z}}$ Data are given by mean \pm standard deviation based on 3 samples.

The superscript a next to the average content values in the Table (Tukey Homogeneous Groups) indicates statistically homogeneous groups. The presence of the indicator designates the lack of statistically significant difference between them. 
Table 3. The concentrations of metals in soils and drill cuttings

\begin{tabular}{|c|c|c|c|c|c|}
\hline Sample & $\mathrm{Cd}$ & $\mathrm{Cr}$ & $\mathrm{Cu}$ & $\mathrm{Ni}$ & $\mathrm{Pb}$ \\
\hline Soil & $1.23 \pm 0.31$ & $19.04 \pm 1.2$ & $0.51 \pm 0.2$ & $11.265 \pm 5.6$ & $8.80 \pm 0.9$ \\
\hline Drill cuttings & $0.3 \pm 0.01$ & $62.63 \pm 10.1$ & $200 \pm 21.3$ & $39.32 \pm 9.89$ & $20.71 \pm 8.6$ \\
\hline
\end{tabular}

The concentration analysis of metals in vermicompost indicated a reduction in the concentration of metals in relation to the parent mixtures. In the mixtures with $5 \%$ addition of drilling wastes, after 7 days of earthworm residence, the concentration of copper decreased from $14.87 \mathrm{ppm}$ to $4.79 \mathrm{ppm}$, lead dropped from $10.58 \mathrm{ppm}$ to $5.08 \mathrm{ppm}$, nickel - from $9.96 \mathrm{ppm}$ to 5.11 , chromium - from $17.89 \mathrm{ppm}$ to $15.02 \mathrm{ppm}$, cadmium - from $1.07 \mathrm{ppm}$ to $0.067 \mathrm{ppm}$. In the mixtures with $10 \%$ addition of drilling wastes, the concentration of copper reduced from $15.27 \mathrm{ppm}$ to $4.81 \mathrm{ppm}$, lead decreased from $10.84 \mathrm{ppm}$ to $6.65 \mathrm{ppm}$, nickel - from $10.45 \mathrm{ppm}$ to 5.37 , chromium - from $18.85 \mathrm{ppm}$ to $15.53 \mathrm{ppm}$, cadmium - from $1.17 \mathrm{ppm}$ to $0.066 \mathrm{ppm}$. In the mixtures with $15 \%$ addition of drilling wastes, the concentration of copper decreased from $18.43 \mathrm{ppm}$ to $5.54 \mathrm{ppm}$, lead reduced from $11.74 \mathrm{ppm}$ to $7.75 \mathrm{ppm}$, nickel - from $11.86 \mathrm{ppm}$ to 5.44 , chromium - from $20.31 \mathrm{ppm}$ to $16.31 \mathrm{ppm}$, cadmium - from $1.43 \mathrm{ppm}$ to $0.074 \mathrm{ppm}$. The conducted statistical analysis of metal content in the paren mixture and vermicompost is statistically significantly different. Table 4 presents the reduction percentage $(R)$ of each scenario.
The mean $\mathrm{R}$ value for heavy metals ranges from $16.04 \%$ for $\mathrm{Cr}$ in the sample of soil with $5 \%$ drilling waste addition to $94.79 \%$ for $\mathrm{Cr}$ in the soil samples with the $15 \%$ addition of drilling waste. The highest reduction was obtained for cadmium in all the investigated mixtures. Total concentration of $\mathrm{Cu}$ and $\mathrm{Ni}$ was reduced by about $50 \%$, on average, whereas in the case of lead - by more than $35 \%$. The lowest percentage of reduction was obtained for chromium - $16 \%$. In table 5 , the coefficient of correlation between the dose of drilling waste in mixtures and reduction percentage $(\mathrm{R})$ was presented. There is a strong correlation between the drilling waste dose in mixtures and reduction percentage (R) of: $\mathrm{Cd}, \mathrm{Cr}, \mathrm{Pb}, \mathrm{Cu}$, amounting to more than $90 \%$; for chromium, the correlation is high as well, reaching $70 \%$.

Al-Haleem and Abed [2016] assessed the advantage of using earthworms in combination with punch waste and nutrients in remediating drill cuttings contaminated with hydrocarbons. Following 7, 14, and 21 days of vermicompost investigation, a reduction in the concentration of zinc, copper and nickel reaching 50\% was noted already after 7 days. The lowest reduction in the concentration was noted for chromium.

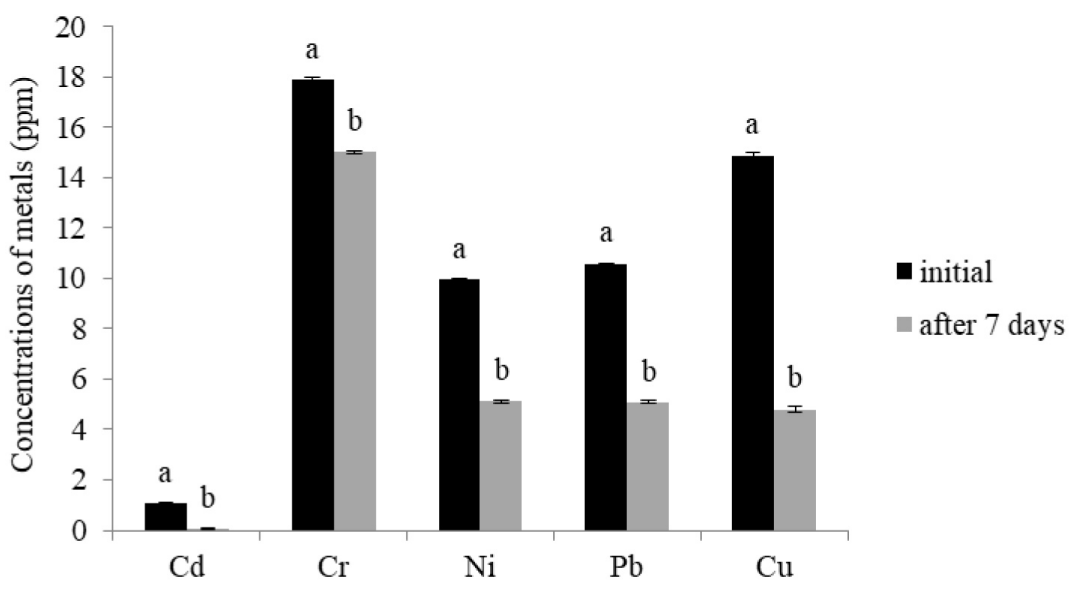

Fig. 1. Concentration of metals in initial of soils with $5 \%$ addition of drilling wastes and vermicomposting Data are given by mean \pm standard deviation based on 3 samples. The superscript ${ }^{a}$ next to the average content values in the Table (Tukey Homogeneous Groups) indicates statistically homogeneous groups. The presence of the indicator designates the lack of statistically significant difference between them 


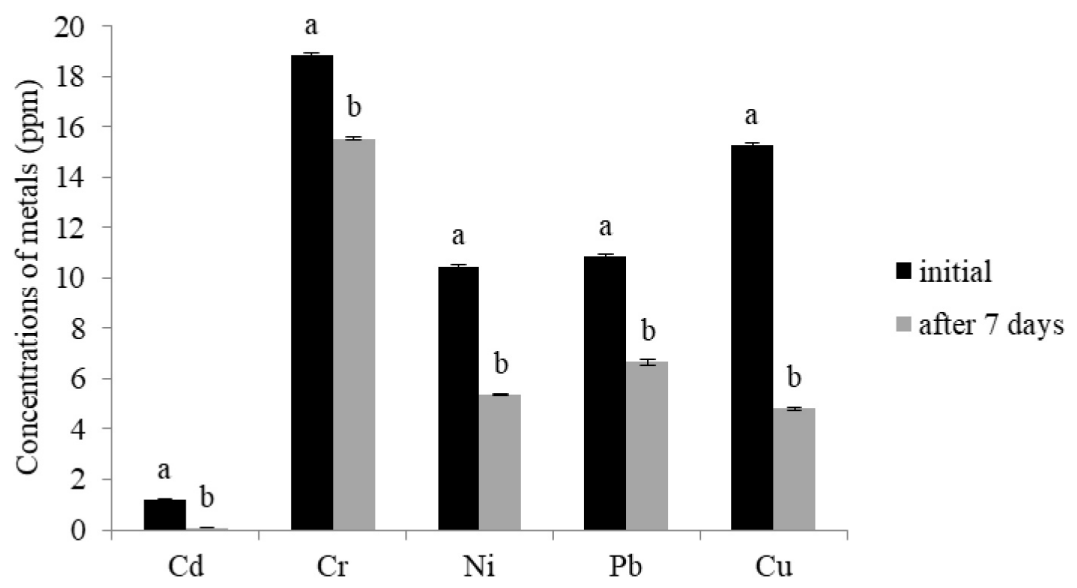

Fig. 2. Concentration of metals in initial of soils with $10 \%$ addition of drilling wastes and vermicomposting Data are given by mean \pm standard deviation based on 3 samples. The superscript ${ }^{a}$ next to the average content values in the Table (Tukey Homogeneous Groups) indicates statistically homogeneous groups. The presence of the indicator designates the lack of statistically significant difference between them

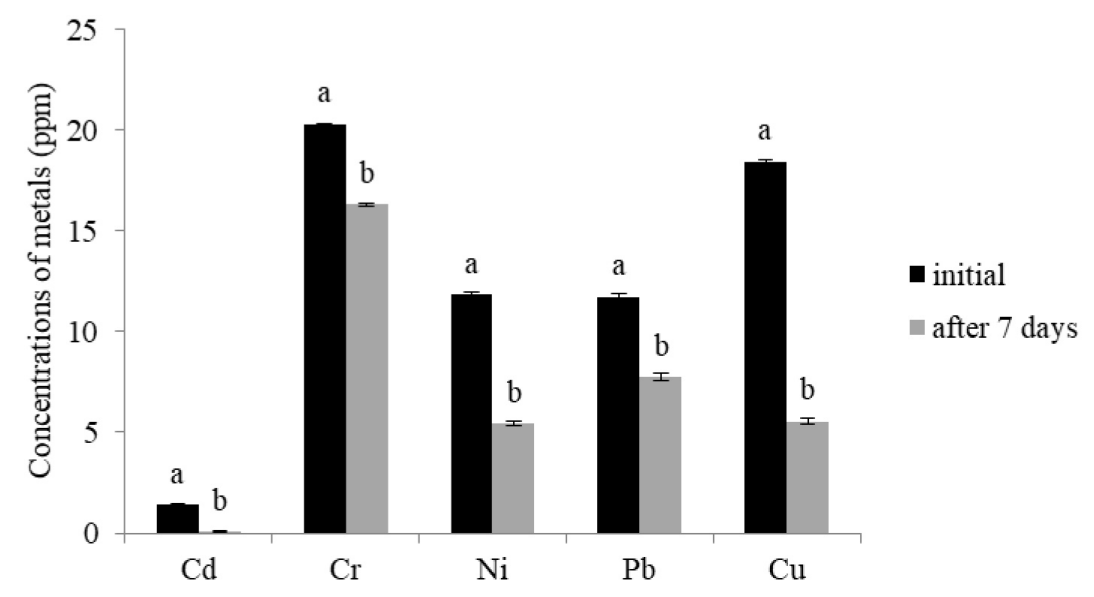

Fig. 3. Concentration of metals in initial of soils with $15 \%$ addition of drilling wastes and vermicomposting Data are given by mean \pm standard deviation based on 3 samples. The superscript ${ }^{\text {a }}$ next to the average content values in the Table (Tukey Homogeneous Groups) indicates statistically homogeneous groups. The presence of the indicator designates the lack of statistically significant difference between them

Table 4. The reduction percentage $(\mathrm{R})$ of mixtures

\begin{tabular}{|c|c|c|c|c|c|}
\hline \multirow{2}{*}{ Mixtures } & \multicolumn{5}{|c|}{$\mathrm{R}[\%]$} \\
\cline { 2 - 6 } & $\mathrm{Cd}$ & $\mathrm{Cr}$ & $\mathrm{Ni}$ & $\mathrm{Pb}$ & $\mathrm{Cu}$ \\
\hline $\mathrm{A} 5$ & 94.2 & 16.04 & 48.69 & 53.6 & 67.78 \\
\hline $\mathrm{A} 10$ & 94.36 & 17.61 & 48.61 & 38.65 & 68.5 \\
\hline A15 & 94.79 & 19.69 & 54.13 & 33.98 & 69.94 \\
\hline
\end{tabular}

Table 5. Correlation between vermicomposting substances and reduction percentage (R)

\begin{tabular}{|c|c|c|c|c|c|}
\hline \multirow{2}{*}{ Sample } & \multicolumn{5}{|c|}{$\mathrm{R}^{2}$ correlation } \\
\cline { 2 - 6 } & $\mathrm{Cd}$ & $\mathrm{Cr}$ & $\mathrm{Ni}$ & $\mathrm{Pb}$ & $\mathrm{Cu}$ \\
\hline Mixtures & 0.93 & 0.99 & 0.74 & 0.92 & 0.96 \\
\hline
\end{tabular}




\section{CONCLUSIONS}

The research indicated that earthworms may be utilized in bioremediation techniques of drilling wastes. The highest reduction, exceeding $90 \%$, was obtained for cadmium in all the examined mixtures with the addition of drilling wastes. The reduction percentage over $50 \%$ was achieved for copper and nickel, whereas more than $35 \%$ was obtained for lead. The lowest reduction was in the case of chromium, amounting to $16 \%$.

\section{REFERENCES}

1. Al-Haleem A.A., Abed K.M. 2016, Treating of oilbased drill cuttings by earthworm, Research Journal of Pharmaceutical, Biological and Chemical Sciences No 7(6), 2088-2094.

2. Enuneku A.A.; Ayobahan S.U. 2016. Sublethal toxic effects of spent oil based drilling mud and cuttings to earthworm Aporrectodea Longa, Journal of Applied Sciences and Environmental Management, 18 (4), 20-29.

3. Fu X., Huang K., Chen X., Li F., Cui G.. 2015. Feasibility of vermistabilization for fresh pelletized dewarted sludge with earthworms Bimastus parvus, Bioresource Technology, 175, 646-650.

4. Getliff J. 2002. Drilling Fluid design and the use of vermiculture for the remediation of drill cuttings, AADE-02-DFWM-HO-16, AADE Technology Conference, Houston, Texas, USA (April 2-3, 2002).

5. He X., Zhang Y., Shen M., Zeng G., Zhou M., Li M. 2016. Effect of vermicomposting on concentration and speciation of heavy metals in sewage sludge with additive materials, Bioresource Technology, 218, 867-873.

6. Hobbelen, P.H.F., Koolhaas, J.E., van Gestel, C.A.M. 2006. Bioaccumulation of heavy

7. Kaliski M., Nagy S., Rychlicki S., Siemek J, Szurlej. 2010., Natural gas in Poland - production, consumption and import till 2030, Mining and Geology, 5 (3), 27-40 (In Polish).

8. Liu X., Hu Ch. i Zhang S. 2005. Effects of earthworm activity on fertility and heavy metal bioavailability in sewage sludge, Environmental International, 31, 874-879.
9. Lukkari T., Taavitsainen M., Soimasuo M., Oikari A., Haimi J. 2004. Biomarker responsesof the earthworm Aporrectodea tuberculata to cooper and zinc exposure: differencesbetween populations with and without eariel metal exposure. Journal of Environmental Pollution 29, 377-386.

10. Lv B., Xing M., Yang J. 2016. Speciation and transformation of heavy metals during vermicomosting of animal manure, Bioresource Technology, 209, $397-401$

11. Macuda J. 2010. Environmental aspects of unconventional gas production, Geological Review, 58 (3) (In Polish).

12. McFarland M.L., Feagley S.E., Provin T.L. 2009. Land application of drilling fluids: Landowner considerations, AgriLife Extension SCS, 8, 1-5

13. Hobbelen PH, Koolhaas JE, van Gestel CA, 2006, Bioaccumulation of heavy metals in the earthworms Lumbricus rubellus and Aporrectodea caliginosa in relation to total and available metal concentrations in field soils, Environmental Pollution, 144, 639-646.

14. Norman M. 2002. Minimizing environmental impacts and maximising hole stability; significance of drilling with synthetic fluids in NZ, New Zealand Petroleum Conference, New Zealand (February 24-27, 2002).

15. Spurgeon, D.J., Hopkin, S.P., Jones, D.T. 1994. Effects of cadmium, copper, lead and zinc on growth, reproduction and survival of the earthworm Eisenia fetida (Savigny): assessing the environmental impact of point-source metal contamination in terrestrial ecosystems, Environmental Pollution, 84, 123-130.

16. Suthar S., Singh S., Dhawan S. 2008. Earthworms as bioindicator of metals $(\mathrm{Zn}, \mathrm{Fe}, \mathrm{Mn}, \mathrm{Cu}, \mathrm{Pb}$ and $\mathrm{Cd}$ ) in soils: Is metal bioaccumulation affected by their ecological category? Ecological Engineering $32,99-10$.

17. Udovic M., Lestan D. 2010. Redistribution of residual $\mathrm{Pb}, \mathrm{Zn}$, and $\mathrm{Cd}$ in soil remediated with EDTA leaching and exposed to earthworms (Eisenia fetida), Environmental Pollution, 158, 2766-2772.

18. Wang L., Zheng Z., Zheng Y., Chao J., Gao Y., Luo X., Zhang J. 2013. Biostabilization enhancement of heavy metals during the vermiremediation of sewage sludge with passivant, Journal of Hazardous Materials, 244-245, 1-9. 